\title{
Implementation of nagari expansion policy in Nagari Preparation for Koto Gadang Jaya, Kinali District, West Pasaman Regency
}

\section{Implementasi kebijakan pemekaran nagari dalam Nagari Persiapan Koto Gadang Jaya, Kecamatan Kinali, Kabupaten Pasaman Barat}

\author{
Annisa Hanif ${ }^{1}$ \& Dimas Subekti ${ }^{* *}$ \\ ${ }^{1}$ Department of Government Science, Faculty of Social and Political Sciences, \\ Universitas Muhammadiyah Yogyakarta \\ ${ }^{2}$ Master of Government Affairs and Administration, Jusuf Kalla School of Government, \\ Universitas Muhammadiyah Yogyakarta \\ Address: ${ }^{1}$ Gedung E2 Lt. Kampus Terpadu UMY J1. Brawijaya, Kasihan, Bantul, \\ Special Region of Yogyakarta, Indonesia 55183 \\ ${ }^{2}$ Gedung Pascasarjana Lt. 2 Kampus Terpadu UMY Jl. Brawijaya, Kasihan, Bantul, \\ Special Region of Yogyakarta, Indonesia 55183 \\ E-mail:dsubekti05@gmail.com
}

Article History: 04 February 2021; Accepted 18 October 2021; Published Online 01 December 2021

\begin{abstract}
The regional government of the West Pasaman Regency has implemented the nagari arrangement using the expansion of nagari. However, there are problems regarding the policy of nagari expansion in the Nagari Preparation of Koto Gadang Jaya. Therefore, this study aims to determine the strategies and problems of expanding the preparatory nagari in Koto Gadang Jaya, West Pasaman Regency. This research is qualitative research using a descriptive approach. Data collection techniques used interviews and documentation. This study used Edward III theory with communication variables, resources, dispositions, and bureaucratic structures. The research findings showed several problems related to implementing the expansion policy of the Nagari Preparation Koto Gadang Jaya; first, on communication variables in the indicators of transmission, clarity, and consistency; second, on the resource variable in human resources, financial resources, and infrastructure facilities indicators; third, the bureaucratic structure variable in the standard operating procedure indicators and fragmentation. Meanwhile, the excellent variable is disposition. This research concluded that the implementation of the policy of expanding the Nagari Preparation Koto Gadang Jaya has not been going well; several problems must be resolved by the party responsible for the policy.
\end{abstract}

Keywords: expansion of nagari; policy implementation; preparation nagari

\begin{abstract}
Abstrak
Pemerintah daerah Kabupaten Pasaman Barat telah menerapkan penataan nagari dengan menggunakan pemekaran nagari. namun, terdapat permasalahan mengenai kebijakan pemekaran nagari di Nagari Persiapan Koto Gadang Jaya. Maka daripada itu, penelitian ini bertujuan untuk mengetahui bagaimana strategi dan persoalan implementasi kebijakan pemekaran Nagari Persiapan Koto Gadang Jaya, Kecamatan Kinali, Kabupaten Pasaman Barat. Penelitian ini merupakan penelitian kualitatif dengan menggunakan pendekatan deskriptif. Teknik pengumpulan data menggunakan wawancara dan dokumentasi. Penelitian ini menggunakan teori Edward III dengan variabel komunikasi, sumber daya, disposisi dan struktur birokrasi. Temuan penelitian menunjukkan bahwa terdapat beberapa permasalahan terkait implementasi kebijakan pemekaran Nagari Persiapan Koto Gadang Jaya. Pertama pada variabel komunikasi dalam indikator transmisi, kejelasan dan konsistensi. Kedua pada variabel sumber daya dalam indikator sumber daya manusia, sumber daya dana dan fasilitas sarana prasarana. Ketiga pada variabel struktur birokrasi dalam indikator standar operating procedur dan fragmentasi. Sedangkan variabel yang sudah baik yakni pada disposisi. Kesimpulan penelitian ini adalah implementasi kebijakan pemekaran Nagari Persiapan Koto Gadang Jaya belum berjalan dengan baik, terdapat beberapa permasalahan yang harus di selesaikan oleh pihak yang bertanggungjawab dalam kebijakan tersebut.
\end{abstract}

Kata kunci: pemekaran nagari; implementasi kebijakan; nagari persiapan 


\section{Introduction}

The regional government of the West Pasaman Regency conducts nagari's arrangement. Based on West Sumatera Provincial Regulation number 7 of 2018, article 1 paragraph (2) states that nagari is a geological and historical customary law community unit, has boundaries in certain areas, has its assets, has the authority to choose its leader by deliberation, and regulates and manages interests local community based on the philosophy and customary code, customs of basandi syara'-syara' basandi kitabullah and based on local origins and customs within the province of West Sumatera. Customs of basandi syara'syara' basandi kitabullah is an order closely held as the basis for the relationship between customs and religion (Muftisany 2015). Nagari's arrangement was carried out by the West Pasaman Regency government using the expansion of nagari. Regional expansion occurred not only at the provincial level but also at the level of the district/city. The phenomenon of regional expansion was driven by several factors like current regulations already offering a tremendous incentive for regional expansion proposals to propagate (Herawati 2013). Regional expansion in Indonesia is one approach that is quite favored in implementing regional government and efforts to increase village development, including in West Sumatera Province (Arifah 2019). The expansion of nagari is needed as a breakthrough to provide accessible services to the community and accelerate development. The equitable development of facilities and infrastructure supports the social, economic, and cultural sectors through professional, transparent, and accountable nagari governance. The expansion of nagari is intended to improve public services to accelerate community welfare and accelerate development. It is also part of an effort to improve the capacity of the village government in shortening the range of government control to increase the effectiveness of government administration and development management (Basri 2015).

Overall, the number of nagari developed by the West Pasaman Regency was 72 preparatory nagari (Indrawati 2018). In some of the divided nagari, Nagari Tinggam Harapan, Nagari Wonosari, and Nagari Preparation for Koto Gadang Jaya experience problems. The problem in Nagari Tinggam Harapan is that people are blocking the progress of the expansion in the nagari. This problem led to protests and demonstrations from the community. Thousands of nagari residents preparing for Tinggam Harapan at the West Pasaman Regent's Office demanded that the preparatory Nagari in Tingam Harapan is established immediately (Dika 2019).

Public policy is a road map for action, and it refers to a larger framework that entails putting a philosophy, principle, vision, and choice into action through numerous programs, projects, and activities (Khan \& Khandaker 2016). Competence in implementing public policies is considered essential to get effective results. Fostering good public governance and effective public leadership generates relationships for implementing sustainable policies (Muhammad 2014). Public policymakers will be aided in improving policy execution through collaborative policy creation and adaptive policy implementation. Policy design can be enhanced by collaboration and discourse between upstream and downstream parties (Ansell et al. 2017). The central government bestows large amounts of funds on local actors to implement public policies. As a result, regional actors create networks for centrally defined and funded projects with public service objectives (Klaster et al. 2017). Public policy requires networks to solve their problems. Public policies implemented by public service organizations have shifted from a hierarchy to a network. Network forms are particularly suited to handling issues to facilitate public services (Ferlie et al. 2011).

This research must be carried out in the Nagari Preparation for Koto Gadang Jaya because several problems occur. First, the head of the Nagari Preparation for Koto Gadang Jaya said that each preparatory nagari only received village funds from the main nagari amounting to Rp 225,000,000.00 per year. Nagari Preparation for Koto Gadang Jaya have not been able to enjoy village funds as a whole and have not been free to accelerate the implementation of the nagari government itself. Secondly, until 2020 the Nagari Preparation for Koto Gadang Jaya is still not definitive nagari even though the policy for the expansion of nagari in West Pasaman was targeted to be completed in 2018, as stated in the West Pasaman Regional Medium Term Development Plan 2016-2021 (Junir 2016). The Head of the 
West Sumatera Provincial Secretariat Government Bureau, MAR, explained that "to become a definitive nagari, the preparatory nagari in West Pasaman must immediately compile the nagari apparatus and it will be evaluated after a maximum of 3 years suppose within one year it meets the requirements. In that case, the preparatory nagari can be submitted to the Ministry of Home Affairs to request a village / nagari register code registered nationally. For that, the preparatory nagari must immediately determine the boundaries between its territories" (Setyo 2017).

Third, some problems occur about Ulayat land. Ulayat land is a parcel of land whose rights belong to a customary law community. The pattern of land ownership in Minangkabau is not individual but communal property, such as belonging to tribes, clans, and nagari. The regeneration or process of inheriting the land is based on a social system with a matrilineal pattern (maternal lineage), namely from Mamak to nephew (Rasyad 2019). According to GUS as the representative of the Kinali Nagari Consultative Body, confirmed through an interview, explaining that in the Nagari Preparation for Koto Gadang Jaya, there was an inequality problem between Ninik Mamak and the government and an overlap related to the issue of releasing customary land which would later be built by an office. It is important because one of the nagari conditions is to expand the island's availability, which will later become the nagari government office building.

Previous research by Tussadiah (2014) discussed the implementation of the regional expansion policy, explaining that the governing law provisions had implemented the implementation stages of the regional expansion policy of East Luwu Regency and North Mamuju Regency. The factors that support the implementation of the regional expansion policy are potential natural resources, investment (investment), transportation and communication infrastructure, openness to outsiders, and public (community) support. Virli C Makasili and Florence D J Lengkong (2020) explained that the regional expansion policy's implementation influences improving public services. Furthermore, Basri (2015) found that the expansion of the northern Tandikek Nagari was quite effective in goal achievement, integration, and adaptation.

Meanwhile, Harmantyo (2010) explained that the more areas there are expansions, the more potential for spatial conflict. The number of boundaries between regions as a source of conflict is increasing. Haikal (2019) also explained the conflict resolution of Nagari Preparation for South Padang Laweh with Nagari Limo Koto. Furthermore, Astuti (2011) found that most of the new autonomous regions resulting from the regional expansion in Indonesia are still low. Several obstacles can be identified, including constraints on personnel resources, financial resources, and infrastructure.

Based on previous research, several studies explained the implementation of the regional expansion policy, both in terms of stages, influence on public services, and expansion effectiveness. Furthermore, several studies also explained conflicts and resolutions in regional expansion. Therefore, this research aims to complement research on implementing the regional expansion policy to see the strategy and policy issues for expanding the Nagari Preparation for Koto Gadang Jaya. Therefore, this study will discuss the strategies and problems in implementing the nagari expansion policy in Nagari Preparation for Koto Gadang Jaya.

\section{Research Method}

This research took place in the Nagari Preparation for Koto Gadang Jaya, Kinali District, West Pasaman Regency, West Sumatera Province. This type of research is qualitative research using a descriptive approach because it examines directed, in-depth, and systematically the strategy and policy problems of expanding the Nagari Preparation for Koto Gadang Jaya. This research collected data using interviews and documentation. Interview sources were the head of Nagari Government of West Pasaman Regency, the Head of Kinali Nagari, the Nagari Consultative Body (BPN) Kinali, the Team for the formation of the Nagari Preparation of Koto Gadang Jaya, and Ninik Mamak Nagari for the preparation for Koto Gadang Jaya. Ninik Mamak is central to Minangkabau culture and tradition, the highest institution in upholding 
customs. The documentation data used in this study were the documents of the Regent of West Pasaman Regency regarding the formation of the nagari for the preparation of Koto Gadang Jaya, the document for the work report of the team for the formation of the Nagari Preparation of Koto Gadang Jaya, and the budget document for the expansion of the Nagari Preparation for Koto Gadang Jaya. The data analysis technique used in this research was descriptive analysis.

The descriptive analysis explains the phenomenon through three stages: data reduction, which is an analysis by transforming raw data in the form of data obtained in the field, then presenting the data, arranging complex data and information into a systematic form so that it becomes simple and will provide data conclusion (Moleong 2010). The raw data obtained in this study came from direct interviews regarding the expansion of the Nagari Preparation for Koto Gadang Jaya and documentation. Then, the data was analyzed, arranged in a systematic form to obtain research results. Furthermore, from the results of these studies, the authors draw research conclusions.

\section{Results and Discussion}

Edward III (in Rifdan 2012) stated that implementation could start from an abstract condition and the requirements for successful policy implementation. There are four public policy variables: communication, resources, dispositions or attitudes, and bureaucratic structures. According to Edward III (Ruhana \& Yuliana 2013). Four variables influence policy implementation. The first is communication, the successful implementation of public policies. One of the aspects that must be fulfilled so that implementers know what to do is that the communication process goes well. These two resources are essential factors for effective policy implementation. Even though the policy has been communicated clearly and consistently, the implementation will not be effective if it lacks the resources to implement it. The three dispositions show the attitude of the implementor. If the implementor has a good attitude, he will carry out policies and what the policymaker wants. The four bureaucratic structures are characteristics, norms, and relationships that repeatedly occur in executive bodies with a relationship, both potential and actual, with what they have in carrying out policies. Maldun (2016) used Edward III's theory to explain the implementation of the Regional Expansion Policy in the North Mamuju Regency. Makasili \& Lengkong (2020) also used Edward III's theory to explain implementing the regional expansion policy on improving public services in Apeng Sembeka Village, Sangkub District Bolaang Mongondow Utara Regency.

Therefore, the implementation of the nagari expansion policy in the Nagari Preparation of Koto Gadang Jaya was measured using the Edward III theory. The objective reason for choosing to use this theory is because this research will explain the implementation of policies related to the strategy and problems of the expansion of nagari. Therefore, the variables in Edward III's theory can make it easier for this research to focus on explaining the problem. The strategy and policy issues for expanding the Nagari Preparation for Koto Gadang Jaya will be explained as follows.

\section{Communication}

Communication plays a vital role in implementing policies (Supriadi 2011). In communication, there are several indicators, such as transmission, clarity, and consistency. A policy must be implemented appropriately. Then, the implementation rules are accepted and socialized clearly and precisely, clarity and accuracy communication is essential to measure in implementing a policy. Otherwise, the implementers will be confused about what they should be doing (Ridwan 2017). The transmission in policy communication is that those who implement decisions must know what to do. Policy decisions and orders must be passed on to the right person before policy decisions and orders are followed (Ramadani 2019). The following will display Figure 1 of the top-down transmission of the nagari expansion policy in the Nagari Preparation for Koto Gadang Jaya. 


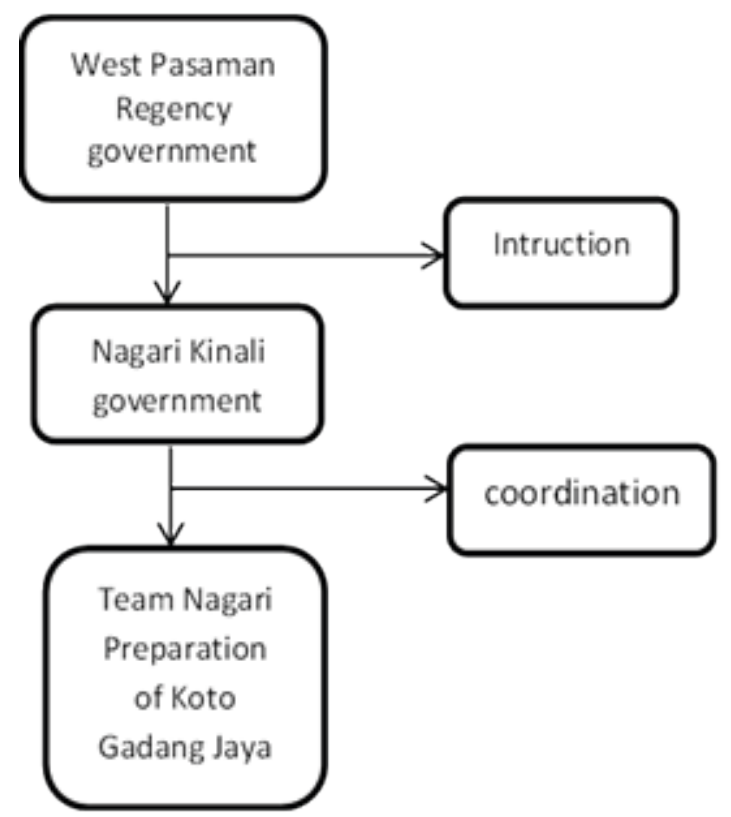

Figure 1.

Top-down transmission from the expansion policy of Nagari Preparation for Koto Gadang Jaya Source: Primary data

Figure 1 shows how to coordinate the people responsible for expanding the Nagari Preparation for Koto Gadang Jaya. The top-down coordination method is in the form of instructions. The West Pasaman Regency government instructed the Kinali Nagari government downward the administrative requirements that the preparatory nagari must complete being expanded and defined. Furthermore, the Kinali Nagari government continued the instruction to the team to form the Nagari Preparation for Koto Gadang Jaya. After receiving these instructions, the formation team prepared the administrative requirements to expand the Nagari Preparation for Koto Gadang Jaya.

Table 1.

Similarities and differences of opinion regarding the expansion of nagari policies

\begin{tabular}{lll}
\hline \multicolumn{1}{c}{ Institution } & \multicolumn{1}{c}{ Similarities } & \multicolumn{1}{c}{ Differences } \\
\hline $\begin{array}{l}\text { West Pasaman Regency } \\
\text { Government }\end{array}$ & $\begin{array}{l}\text { Nagari expansion policy to } \\
\text { streamline administrative services to } \\
\text { the community }\end{array}$ \\
$\begin{array}{l}\text { Nagari expansion policy to } \\
\text { streamline administrative services to } \\
\text { the community }\end{array}$ \\
$\begin{array}{l}\text { The Nagangan Kan } \\
\text { (BPN) }\end{array}$ & $\begin{array}{l}\text { Nagari expansion policy to } \\
\text { streamline administrative services to } \\
\text { the community }\end{array}$ \\
$\begin{array}{l}\text { The formation team for the Nagari } \\
\text { Preparation for Koto Gadang } \\
\text { Jaya }\end{array}$ & $\begin{array}{l}\text { Nagari expansion policy to } \\
\text { streamline administrative services to } \\
\text { the community Mamak }\end{array}$ \\
\hline
\end{tabular}

Source: Primary data

Clarity is meant that information sources should not provide contradictory interpretations because it will make it difficult for implementers to carry out policy objectives (Permatasari 2020). There are five institutions involved in expanding the Nagari Preparation for Koto Gadang Jaya, namely the West Pasaman Regency Government, the Kinali Nagari Government, the Nagari Consultative Body (BPN), Ninik Mamak, and the formation team for the Nagari Preparation for Koto Gadang Jaya. Some of these institutions have various perspectives or views on expanding the Nagari Preparation for Koto Gadang Jaya, as explained in Table 1. 
Based on Table 1, there are similarities in perspective between the West Pasaman Regency Government, the Kinali Nagari Government, The Nagari Consultative Body (BPN), and the Nagari Preparation for Koto Gadang Jaya Team regarding nagari expansion. However, there are different perspectives from Ninik Mamak, who believes that the expansion of nagari will later change Nagari Custom Density (KAN). Ninik Mamak still believes that Kinali Nagari must remain the custom head, and there is only one Nagari Custom Density (KAN). Nagari Custom Density (KAN) is a customary mediation institution that facilitates peace for parties in customs disputes. Ninik Mamak is central to Minangkabau culture and tradition, the highest institution upholding customs (Wiryomartono 2014). This difference in views led the West Pasaman Regency government and the Kinali Nagari Government, the Nagari Consultative Body (BPN), and the formation team to invite Ninik Mamak to discuss finding a solution to these differences. The conflict in the policy of expansion of nagari is caused by a fundamental difference between customary law and state regulations administratively as a constraining structure. The idea of the expansion of nagari not impacting customary land ownership is difficult to understand because it uses a customary law perspective. The Customary Law views that Ulayat land is regulated by the Ninik Mamak, Nagari Custom Density (KAN) and the nagari government with the Minangkabau custom (Haikal 2019).

Consistency is related to the information conveyed by the West Pasaman Regency government to the Kinali Nagari government regarding the objectives and targets of nagari expansion policies. In Kinali Nagari, there are Ninik Mamak, The Nagari Consultative Body (BPN), and Kinali Nagari Governments. The Kinali Nagari government conveyed information about the objectives and targets of the nagari expansion policy to the Nagari Preparation for Koto Gadang Jaya formation team, as explained in Figure 2.

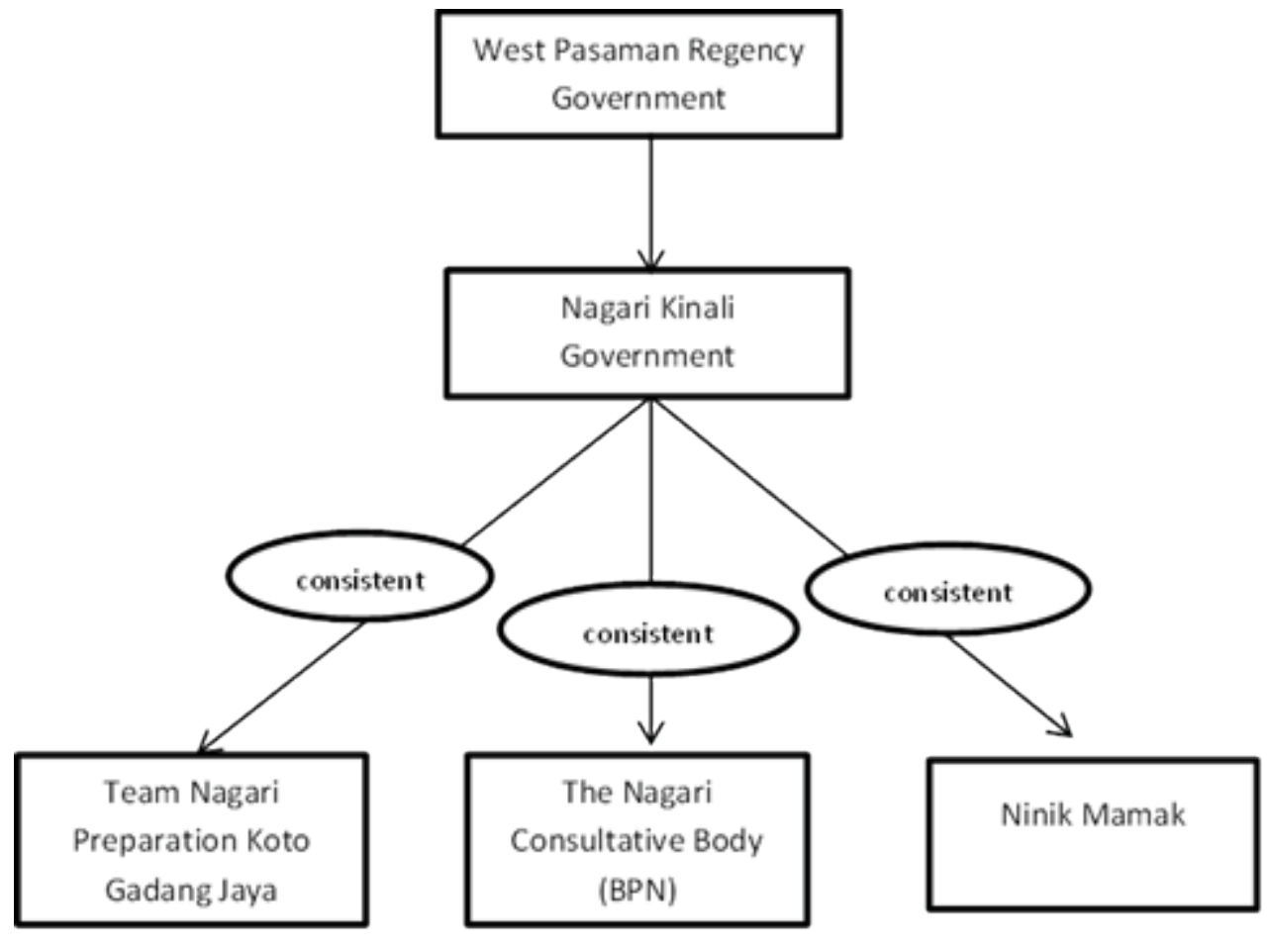

Figure 2.

Consistency of information on nagari expansion policies Source: Primary data

Figure 2 shows the flow of information provided by the West Pasaman Regency government to the Kinali Nagari government and forwarded to the team Nagari Preparation for Koto Gadang Jaya regarding the objectives and targets of the nagari expansion policy. Information regarding the targets for the expansion of nagari was conveyed consistently from the West Pasaman Regency Government to Nagari 
Preparation for Koto Gadang Jaya team and the Nagari Consultative Body (BPN), shown by preparing administrative requirements for the Nagari Preparation for Koto Gadang Jaya that the formation team and Kinali Nagari can understand.

Meanwhile, the consistency of information regarding the purpose of expanding Nagari Preparation for Koto Gadang Jaya is still a problem, seen from different views of understanding or disagreement about the purpose of expanding nagari, especially from Ninik Mamak. The difference in understanding about the division of nagari between the West Pasaman Regency Government and the Kinali Nagari and Ninik Mamak governments shows that there are still inconsistencies in conveying information related to the objectives of the expansion of Nagari Preparation for Koto Gadang Jaya.

\section{Resource}

Resources are an essential factor in implementing public policy. Resources in implementing public policies include adequate staff, information, funding, authority, and other supporting facilities (Ramdhani \& Ramdhani 2017). In the resource variable, there are two indicators: human resources and financial resources and facilities. The human resources of six people became the team for forming the Nagari Preparation for Koto Gadang Jaya. The formation team was formed through an open selection system. There was a direct interview test to select six people who became members of the formation team. The selected six people had representatives from three-element. There were representatives from the West Pasaman Regency government, Kinali Nagari government, and the community, as shown in Table 2.

Table 2.

Representative elements of the Nagari Preparation for Koto Gadang Jaya Preparatory

\begin{tabular}{|c|c|c|}
\hline Name & Position & Representative \\
\hline Yusnimar, S.Pd. & $\begin{array}{l}\text { Person in charge of the team } \\
\text { for the formation of the nagari } \\
\text { preparation }\end{array}$ & $\begin{array}{l}\text { West Pasaman Regency } \\
\text { Government }\end{array}$ \\
\hline Ismail, S.Pd.I. & Secretary & $\begin{array}{l}\text { Community Nagari Preparation } \\
\text { for Koto Gadang Jaya }\end{array}$ \\
\hline Agus Hariyanto, S.Pd. & $\begin{array}{l}\text { Head of general affairs and } \\
\text { planning }\end{array}$ & $\begin{array}{l}\text { Community Nagari Preparation } \\
\text { for Koto Gadang Jaya }\end{array}$ \\
\hline $\begin{array}{l}\text { Yeni Rismawati, S.Pd. } \\
\text { Syukri }\end{array}$ & $\begin{array}{l}\text { Head of financial affairs } \\
\text { Head of government affairs }\end{array}$ & $\begin{array}{l}\text { Kinali Nagari Government } \\
\text { Community Nagari Preparation } \\
\text { for Koto Gadang Jaya }\end{array}$ \\
\hline Solikhun & Head of people's welfare & $\begin{array}{l}\text { Community Nagari Preparation } \\
\text { for Koto Gadang Jaya }\end{array}$ \\
\hline
\end{tabular}

Based on Table 2, the representatives in the formation team of the Nagari Preparation for Koto Gadang Jaya have not represented various parties. There is no representative from the Nagari Consultative Body (BPN) and the Ninik Mamak. The number of representatives from the community so that in carrying out the policy of expanding the Nagari Preparation for Koto Gadang Jaya was less effective. Therefore, institutionally and personally, the team for the formation of the Nagari Preparation for Koto Gadang Jaya does not yet have sufficient capacity to carry out the policy of nagari expansion.

Meanwhile, the implementation of the regional expansion policy, which is carried out in several stages that are mature, planned, and systematic, dramatically affects the quality of life of the community, in the aspects of development, public services, and in improving the welfare (Makasili \& Lengkong 2020).

Financial resources and facilities, the village budget provided by Nagari Preparation for Koto Gadang Jaya are IDR 225.000.000 per year. The head of nagari preparation confirmed this, Koto Gadang Jaya community welfare affairs, that the funding budget given by the Kinali Nagari Government in 2017 was IDR 200.000.000, then there was an increase in the following year of IDR 225.000.000. The budget includes salaries or honoraria and operational costs for the team to form the Nagari Preparation for Koto Gadang Jaya. Based on an interview with Kinali Nagari, the source of the funds came from village 
funds from the central government program. The funds are disbursed annually to pay for the salaries of six people and operational costs. The determination of the salary level for the Nagari Preparation for Koto Gadang Jaya team is stated in the Decree of the West Pasaman Regent Number 188.45/635/ Bup-Pasbar-2017 concerning the formation of the team and the secretariat of the preparatory nagari government formation team in the West Pasaman Regency. When the Nagari Preparation for Koto Gadang Jaya status was still not definitive, the budget was sufficient. However, if it is definitive, of course, it will be lacking. Therefore, if the Nagari Preparation for Koto Gadang Jaya is definitive, it will automatically get the Village register number from the central government. Thus, the Village funds can go directly to the village without an intermediary Nagari Induk government.

Meanwhile, related to the readiness of facilities and infrastructure in implementing the Nagari Preparation for Koto Gadang Jaya expansion. Kinali Nagari explained that the infrastructure facilities not prepared are building the Nagari Preparation for Koto Gadang Jaya government office. Therefore, the nagari preparation team, Koto Gadang Jaya, still rents the existing building to become an office. The Kinali Nagari Government facilitates the leasing of the building. Everything that can be used as a support tool in achieving a goal is facilities and infrastructure. The availability of adequate facilities and infrastructure will contribute to a better public service network. The primary function of facilities and infrastructure is to speed up service, provide higher quality work, comfort, and create a sense of satisfaction for persons in need of service (Daraba et al. 2018).

\section{Disposition}

Disposition in policy implementation means the implementers' tendency, desire, or agreement to carry out a policy to implement a suitable policy (Indah \& Hariyanti 2018). The team for forming the Nagari Preparation for Koto Gadang Jaya addresses the problems by providing existing solutions either by holding meetings, deliberations, or coming directly to explain to Ninik Mamak about the problems. The attitude of the formation team in dealing with these problems is described in Table 3.

Table 3.

The attitude of implementers towards problem-solving

\begin{tabular}{|c|c|}
\hline Problem & Solution \\
\hline $\begin{array}{l}\text { There is an inconsistency of information in } \\
\text { understanding the purpose of the expansion of } \\
\text { nagari. There is a difference in understanding, } \\
\text { especially between Ninik Mamak and the nagari } \\
\text { government }\end{array}$ & $\begin{array}{l}\text { Together with the Kinali Nagari Government, met } \\
\text { Ninik Mamak to explain the real purpose of the } \\
\text { expansion of this nagari to facilitate administrative } \\
\text { services to the community }\end{array}$ \\
\hline $\begin{array}{l}\text { There was a problem with Ulayat land ownership } \\
\text { rights }\end{array}$ & $\begin{array}{l}\text { Holding a meeting with traditional leaders to } \\
\text { discuss and resolve the Ulayat land dispute }\end{array}$ \\
\hline $\begin{array}{l}\text { Ninik Mamak feared that the expansion of the } \\
\text { nagari would destroy the customary customs }\end{array}$ & $\begin{array}{l}\text { Holding deliberations with the West Pasaman } \\
\text { Regency Government, Kinali Nagari Government, } \\
\text { Nagari Consultative Body (BPN), and Ninik } \\
\text { Mamak. To explain to Ninik Mamak that the } \\
\text { expansion of this nagari will not change the } \\
\text { existing customary order }\end{array}$ \\
\hline
\end{tabular}

Source: Primary data

From Table 3, the Nagari Preparation for Koto Gadang Jaya team faces or addresses the problems by holding meetings and deliberations. More than that, the formation team also met directly with Ninik Mamak to explain the purpose of expanding the nagari. It aims to minimize the inconsistency of information understood at the Ninik Mamak level to create a shared understanding of the objectives of the expansion of the nagari. The formation team also responded to the difference in views between Ninik Mamak and the nagari government regarding the expansion of nagari, disturbing existing customs. The team for forming the Nagari Preparation for Koto Gadang Jaya held deliberations with the West Pasaman Regency government, the Kinali Nagari Government, and the Nagari Consultative Body (BPN) with Ninik Mamak. This meeting discussed these different views to reach a mutually agreed solution for expanding the Nagari Preparation for Koto Gadang Jaya. 


\section{Bureaucratic structure}

Bureaucratic structures are all organizational instruments comprehensive and structured (Lukitasari et al. 2017). In the bureaucratic structure variable, there are two indicators, called standard operating procedure and fragmentation. Figure 3 shows the standard operating procedure of the policy for the expansion of Nagari Preparation for Koto Gadang Jaya.

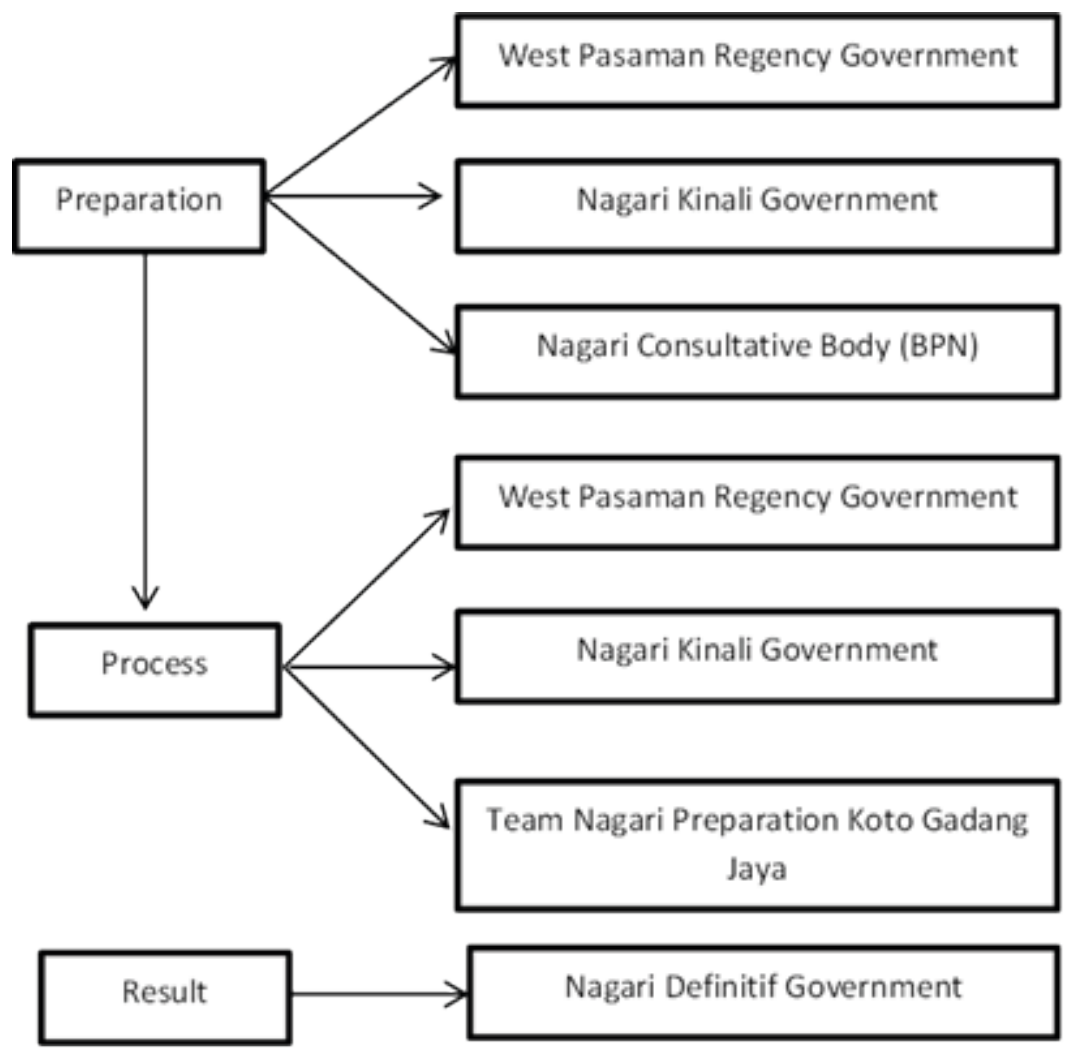

Figure 3.

Standard operating procedure for the expansion of Nagari Preparation for Koto Gadang Jaya Source: Governor of West Sumatera (2017)

Figure 3 explains the Standard Operating Procedure (SOP) to expand the Nagari Preparation for Koto Gadang Jaya. Starting from the preparation stage, the parties involved are the West Pasaman Regency government. The West Pasaman Regency Government plays a role in planning the nagari expansion policy after the West Pasaman Regency government disseminates the plan to the Kinali Nagari Government. Second, the Kinali Government plays a role in this nagari expansion policy plan by holding joint discussions with the Nagari Consultative Body to obtain a mutual agreement. Third, the Nagari Consultative Body plays a role in the nagari expansion plan by holding deliberations facilitated by the Kinali Nagari government. The nagari deliberation is attended by the Kinali Nagari Government, the Nagari Consultative Body, nagari institutions, and elements of society.

In the process stage, the party is the Nagari Preparation for Koto Gadang Jaya. The formation team will be formed after the West Pasaman Regency government accepts the results of the nagari deliberations. This formation team is tasked with preparing the requirements for forming the nagari preparatory government by statutory provisions. The Nagari Preparation for Koto Gadang Jaya Team is also responsible for forming the preparatory nagari to become the definitive nagari. The preparation requires determining administrative boundaries, managing operational budgets, forming organizational structures, appointing nagari apparatuses, preparing basic facilities, building government facilities and infrastructure, collecting data on population economic potentials. The second is the parties involved 
in the nagari expansion policy process stage. The Kinali Nagari Government plays a role in receiving reports on implementing the nagari preparatory government. Third, the parties involved in the nagari expansion policy process include the West Pasaman Regency Government, which receives reports on preparing the Nagari Preparation for Koto Gadang Jaya through Kinali Nagari. The Nagari Government of West Pasaman Regency also verifies the feasibility of the Nagari Preparation for Koto Gadang Jaya. A draft regional regulation will be drawn up and submitted to the Regional People's Representative Assembly for discussion and agreement if it is feasible. Moreover, the draft regional regulation is submitted to the provincial level for evaluation. The evaluation results later determine whether or not it is appropriate to become a definitive nagari.

In the result stage, the parties involved are the definitive nagari government. If the nagari has been determined to be the definitive nagari, then the definitive nagari government is responsible for administering its government. However, in the context of Nagari Preparation for Koto Gadang Jaya, the process of cultivating it has not yet reached the yield stage. Because until now, the Nagari Preparation for Koto Gadang Jaya has not been determined to be the definitive nagari. Nagari Preparation for Koto Gadang Jaya is still in the process stage because it is still waiting for verification and prepares everything to become the definitive nagari.

Another critical aspect of the bureaucratic structure is the presence or absence of fragmentation (Lukitasari et al. 2017). Fragmentation is the distribution of the responsibility for a policy to several different agencies to require coordination (Mustanir \& Jusman 2016). Five parties have responsibility for the expansion of the Nagari Preparation for Koto Gadang Jaya. The five agencies are the Nagari West Pasaman Regency government, the Kinali Nagari Government, the Nagari Consultative Body, Ninik Mamak, and Nagari Preparation for Koto Gadang Jaya. The Nagari Government of West Pasaman Regency must inform the provisions that each nagari must fulfill.

Then, they must discuss it with the Regional People's Representative Assembly, then report it to the Provincial level for evaluation. However, the problem is that the West Pasaman Regency government has not carried out its responsibilities properly. It takes too long to verify the nagari preparatory documents, which prevents them from being discussed with the Regional People's Representative Assembly and reported to the Province for evaluation. The responsibility of the Kinali Nagari Government is to assist the formation team in preparing the data needed and to link the coordination between the nagari government and the formation team. The Nagari Consultative Body is responsible for holding nagari deliberations with various parties to discuss nagari expansion policies. Ninik Mamak ensures that the customs do not change with expanding the Nagari Preparation for Koto Gadang Jaya policy.

Meanwhile, the team preparing the Nagari Preparation for Koto Gadang Jaya has the task of preparing everything related to requirements such as nagari's profiles, regional boundaries, and others so that the Nagari Preparation for Koto Gadang Jaya is worthy of being the definitive nagari. But the problem is that there are no representatives from the nagari formation team from The Nagari Consultative Body (BPN) and Ninik Mamak. Most of them come from the community, so they are less effective. The method of coordination of the three agencies, namely the West Pasaman District Government, communicated with the Kinali Nagari Government, and later the Kinali Nagari Government would inform the formation team. The Kinali Nagari Government became the facilitator to hold a meeting between the West Pasaman Regency government and the formation team.

\section{Conclusion}

The conclusion of this study is implementing the policy of the expansion of the Nagari Preparation for Koto Gadang Jaya using four variables, communication, resources, disposition, and bureaucratic structure. However, there are still some notes related to the implementation of the policy for the expansion of the Nagari Preparation for Koto Gadang Jaya. First, on the communication variable in the transmission indicator, there are still problems regarding land ownership rights that hinder the expansion 
of nagari. Indicator of clarity because Ninik Mamak still has different views on the policy of expansion of nagari. Consistency indicator because there is still inconsistency regarding the delivery of information from the objectives of the expansion of nagari. Second, there is no representative from the Nagari Consultative Body (BPN) and Ninik Mamak on the resource variable in the human resource indicator. Many representatives from the community became less effective in carrying out the policy of expanding the Nagari Preparation for Koto Gadang Jaya. So that institutionally and personally, the team for the formation of the Nagari Preparation for Koto Gadang Jaya does not yet have sufficient capacity to carry out the policy of nagari expansion. The indicator of financial resources and infrastructure facilities still lacks office facilities used by the Nagari Preparation for Koto Gadang Jaya, currently renting buildings owned by the community. The third is the bureaucratic structure variable in the Standard Operating Procedure (SOP) indicator. The Nagari Preparation for Koto Gadang Jaya is still in the expansion process and has not yet become definitive. On the Fragmentation indicator, because the West Pasaman Regency Government has not carried out its responsibilities properly. It took too long to verify the nagari preparatory documents, which prevented them from being discussed with the Regional People's Representative Assembly and reported to the Province for evaluation.

The excellent variable is the disposition because as the implementer of expanding the Nagari Preparation for Koto Gadang Jaya, the formation team has the desire, will, and is serious and committed to carrying out its duties responsibilities proven by the attitude of the formation team in addressing the problems that occurred in the nagari expansion process. Therefore, the implementation of the policy for the expansion of the Nagari Preparation for Koto Gadang Jaya has not been going well. Several problems must be resolved by the party responsible for the policy.

\section{References}

Ansell C, Sørensen E, \& Torfing J (2017) Improving policy implementation through collaborative policymaking. Policy and Politics 45 (3):467-486.

Arifah R (2019) Faktor penyebab pemekaran nagari: Studi kasus Nagari Koto Tinggi Maek Kabupaten Lima Puluh Kota. JISPO 9 (2):135-152.

Astuti SJW (2011) Evaluation on implementation of region expansion policy in Indonesia. International Journal of Policy Studies 2 (2):43-51.

Basri GL (2015) Efektivitas pemekaran Nagari Tandikek Utara Kecamatan Patamuan Kabupaten Padang Pariaman. JOM Fisip 2 (1):1-15.

Daraba D, Guntur M, Kartini F, \& Salam R (2018) The impact of village expansion policy on public service aspects at Sadar Village Bone-Bone District of North Luwu Regency Dahyar. Proceeding of The Education Research Colloquium.

Dika (2019) Selesaikan permasalahan pemekaran nagari, Warga Tinggam Harapan demo ke DPRD. Hariansinggalang.co.id, 14 June. [Accessed 02 January 2021]. https://hariansinggalang.co.id/ selesaikan-pemekaran-nagari-warga-tinggam-harapan-demo-ke-dprd/.

Ferlie E, Fitzgerald L, Mcgivern G, Dopson S, \& Bennett C (2011) Public policy networks and "wicked problems": A nascent solution? Public Administration 89 (2):307-324. https://doi.org/10.1111/ j.1467-9299.2010.01896.x.

Governor of West Sumatera (2017) Decree of the Governor of West Sumatra Number 120/269/Pem 2017 regarding the formation Nagari Preparation for Koto Gadang Jaya. Padang: Governor of West Sumatera.

Haikal F (2019) Model resolusi konflik Pemekaran Nagari. Jurnal Sosiologi Andalas 5 (2):98-114. https://doi.org/10.25077/jsa.5.2.98-114.2019.

Harmantyo D (2010) Pemekaran daerah dan konflik keruangan kebijakan otonomi daerah dan implementasinya di Indonesia. MAKARA of Science Series 11 (1):16-22. https://doi.org/10.7454/ mss.v11i1.220.

Herawati NR (2013) Pemekaran daerah di Indonesia. Jurnal Desentralisasi 11 (1):359-370. https://doi. org/10.37378/jd.2013.1.359-370. 
Indah T \& Hariyanti P (2018) Implementasi kebijakan keterbukaan informasi publik pada Dinas Kominfo Kota Tasikmalaya. Jurnal Komunikasi 12 (2):127-140. https://doi.org/10.20885/komunikasi. vol12.iss2.art3.

Indrawati N (2018) Dari 19 Nagari induk, Kabupaten Pasaman Barat bakal punya 92 Nagari hasil Pemekaran. Padangmedia.com, 12 December. [Accessed 02 January 2021]. https://padangmedia. com/dari-19-nagari-induk-kabupaten-pasaman-barat-bakal-punya-92-nagari-hasil-pemekaran/.

Junir S (2016) Syahiran: Pemekaran nagari tidak akan gnggu sistem adat. Sumbarsatu, 22 December. [Accessed 02 January 2021]. https://sumbarsatu.com/berita/14321-syahiran-pemekaran-nagaritidak-akan-ganggu-sistem-adat.

Khan AR \& Khandaker S (2016) A critical insight into policy implementation and implementation performance. Public Policy and Administration 15 (4):538-548. https://doi.org/10.13165/VPA16-15-4-02.

Klaster E, Wilderom CPM, \& Muntslag DR (2017) Balancing relations and results in regional networks of public policy implementation. Journal of Public Administration Research and Theory 27 (4):676-691. https://doi.org/10.1093/jopart/mux015.

Lukitasari SW, Sulasmono BS, \& Iriani A (2017) Evaluasi implementasi kebijakan pendidikan inklusi. Kelola: Jurnal Manajemen Pendidikan 4 (2):121-134. https://doi.org/10.24246/j.jk.2017.v4.i2. p121-134.

Makasili V, Lengkong FD, \& Kiyai B (2020) Pengaruh implementasi kebijakan pemekaran wilayah terhadap peningkatan pelayanan publik di Desa Apeng Sembeka Kecamatan Sangkub Kabupaten Bolaang Mongondow Utara. Jurnal Administrasi 6 (92):1-27.

Maldun S (2016) Analisis implementasi kebijakan pemekaran daerah di Kabupaten Mamuju Utara. Seminar Nasional, Revolusi Mental dan Kemandirian Bangsa Melalui Pendidikan Ilmu-Ilmu Sosial Dalam Menghadapi MEA 20151 (2):132-144.

Moleong LJ (2010) Metode Penelitian Kualitatif. Bandung: PT. Remaja Rosdakarya.

Muftisany H (2015) Adat Basandi Syara', Syara' Basandi Kitabullah. Republika.co.id, 08 May. [Accessed 15 June 2021]. https://www.republika.co.id/berita/no0x0830/adat-basandi-syara-syara-basandikitabullah.

Muhammad F (2014) Leadership, governance and public policy implementation competencies in the broader public sector. European Journal of Business Management 6 (36):66-74.

Mustanir A \& Jusman (2016) Implementasi kebijakan dan efektivitas pengelolaan terhadap penerimaan retribusi di Pasar Lancirang Kecamatan Pitu Riawa Kabupaten Sidenreng Rappang. Jurnal Ilmiah Akmen 13 (3):542-558.

Permatasari IA (2020) Kebijakan publik (teori, analisis, implementasi, dan evaluasi kebijakan). The Journalish: Social and Government 1 (1):34-38. http://thejournalish.com/ojs/index.php/ thejournalish/article/view/7.

Ramadani T (2019) The implementation of public communication management policy at Ministry of Energy and Mineral Resources. Jurnal Borneo Administrator 15 (1):1-18. https://doi.org/10.24258/ jba.v15i1.369.

Ramdhani A \& Ramdhani MA (2017) Konsep umum pelaksanaan kebijakan publik. Jurnal Publik 1-12. https://doi.org/10.1109/ICMENS.2005.96.

Rasyad M (2019) Pembuatan akta perdamaian dalam penyelesaian sengketa tanah ulayat melalui notaris di Kabupaten Agam. Soumatera Law Review 2 (1):149-200.

Ridwan B (2017) Implementasi kebijakan standar pelayanan minimal di RSUD Undata Provinsi Sulawesi Tengah. Jurnal Katalogis 5 (12):108-117.

Rifdan (2012) Implementasi kebijakan pemekaran daerah dalam mendukung integrasi nasional di Kabupaten Luwu Timur. Jurnal Ilmiah Ilmu Administrasi Publik 1 (1):23. https://doi.org/10.26858/ jiap.v1i1.206.

Ruhana F \& Yuliana Y (2013) Implementasi kebijakan kurikulum tingkat satuan pendidikan. Jurnal Ilmu Administrasi Negara 10: 141-153.

Setyo (2017) 72 nagari mekar di Pasaman Barat, tunggu PJ wali nagari. Semangatnews, 13 May. [Accessed 02 January 2021]. https://www.semangatnews.com/72-nagari-mekar-di-pasamanbarat-tunggu-pj-wali-nagari/. 
Supriadi A (2011) Analisis prakondisi implementasi kebijakan peningkatan kompetensi guru. Jurnal Pendidikan Dan Pembelajaran (JPP) 18 (1):36-46.

Tussadiah H (2014) Luwu Timur pada masa pemerintahan Andi Hatta Marakarma. Thesis, Universitas Negeri Makassar, Makassar.

Wiryomartono B (2014) Ninik Mamak: Motherhood, hegemony, and home in West Sumatra, Indonesia. Perspectives on Traditional Settlements and Communities. Singapore: Springer. 113-131. https:// doi.org/10.1007/978-981-4585-05-7. 